A Royal Devon and Exeter Hospital, Princess Elizabeth Orthopaedic Centre ${ }^{1}$ és a

Pécsi Tudományegyetem KK, Ortopédiai Klinika közleménye ${ }^{2}$

\title{
A link protein szerepe az osteochondrogenesisben \\ Egy állatkísérletes osteochondrodysplasia modell és génterápiája
}

DR CZIPRI MÁTYÁS ${ }^{1}$, DR THAN PÉTER², DR VERMES CSABA²

\section{ÖSSZEFOGLALÁS}

A szerzők egy génmutáción alapuló állatkísérletes modellt ismertetnek, amely alkalmas osteochondrodysplasiák modellezésére és vizsgálatára. Hasonló modellek segítséget nyújtanak a humán chondrodysplasiák kutatásában és genetikai hátterük felderítésében. A modell a hyalin porc extracellularis mátrixában előforduló egyik strukturális molekula, a link protein célzott mutációval kiváltott hiányán, illetve annak transzgének által történő, különböző mennyiségű visszapótlásán alapul. A homozygota mutáció súlyos chondrodysplasiát eredményez, és letális. A különböző mennyiségben helyreállított link protein szintézis biztosítja a túlélést és a skeletális elvátozások dózis dependens gyógyulását eredményezi. A modell a génterápia lehetőségét is magában hordja.

\section{Kulcsszavak: $\quad$ Állatkisérlet; Extrcellularis mátrix fehérjék; Génterápia; Protein; Osteochondrodysplasiák;}

M. Czipri, P. Than, Cs. Vermes: The role of link protein in osteochondrogenesis: an experimental animal model of osteochondrodysplasia with genetic rescue

Authors present an experimental animal model that is based on a genetic mutation and allows to model and investigate osteochondrodysplasias. Similar models are helpful in the research of human osteochondrodysplasias to explore their genetic background. This model is based on the lack of a cartilage extracellular matrix protein, the link protein and its restoration in different amounts, caused by the targeted mutation of the link protein gene and its replacement with a transgene. The homozygous mutation results in severe osteochondrodysplasia and is lethal. When the link protein syntheis is restored at different levels, it prevents perinatal death and cures the skeletal changes in a dose-dependent manner.

Keywords: $\quad$ Animals; Cartilage; Extracellular matrix proteins;

Models, genetic; Proteins - Genetics;

Osteochondrodysplasias; 


\section{BEVEZETÉS}

$\mathrm{Az} \quad$ osteochondrodysplasiák az osteochondralis szövetek örökletes, generalizált fejlődési zavarai. Az egyes chondrodysplasiák előfordulása ritka, de együttesen az előfordulási gyakoriságuk közel $1 / 5000$ (8). A jelenleg ismert több mint 350 kórkép genetikailag heterogén csoportot alkot. Ezen kórképek osztályozása korábban pusztán klinikai megjelenés és radiológiai jellegzetességek alapján történt, de genetikai hátterük robbanásszerű feltérképezése lehetőséget ad a hasonló molekuláris hátterű betegségcsoportok családokba sorolására, és újabb kutatási irányok kijelölésére $(8,13,17)$.

A csontrendszer kialakulása az embrionális korban, és növekedése a születés után döntően az enchondralis csontosodás mechanizmusán keresztül valósul meg. Az embrionális mesenchyma kondenzálódása után chondrocyták jelennek meg és extracellularis mátrix (ECM) termelésükkel létrehozzák a későbbi csontok porcos alapját. Az enchondralis csontosodás során a diaphysisben kezdődve a porcsejtek hypertrophyzálódnak, extracellularis mátrix termelésük megváltozik, erek betörését és ezzel csont progenitor sejtek érkezését segítve elő. A folyamat a csontvégek felé haladva létrehozza az embrionális csontok diaphysisét és metaphysisét, de a végekhez közeledve a csontosodási zónától distalisan chondrocyták proliferációja indul meg, létrehozva a növekedési porcot. Ezek a proliferálódó porcsejtek a hypertrophyzálódás előtt de novo porcot termelnek, amely az epiphysis fuga porcállományát alkotja. A növekedési porc folyamatosan újratermelődő porcállománya megvédi a porcos epiphysist az elcsontosodástól, valamint alapot biztosít a chondrocyták differenciálódására (prehypertrophia, hypertrophia) és ezzel biztosítja a lineáris csontnövekedést. A porcos epiphysisek centrumában beinduló chondrocyta differenciálódással pedig megkezdődik az epiphysis csontmagok kialakulása az előbbiekhez hasonló események eredményeként (5). Ezen összetett folyamatok időben és térben specifikus és direkt genetikai kontroll alatt állnak (8).

A chondrocyták által termelt fehérjék építik fel a porc ECM-jét, amelynek épsége egyik alapfeltétele a hibátlan skeletális fejlődésnek. A hyalin porc ECM strukturális molekulái a kollagének, proteoglikánok, glikoproteinek és glükózaminoglikánok. A porc legfőbb fibrilláris alkotóeleme a II-es típusú kollagén, de kisebb mennyiségben más porcspecifikus kollagének is jelen vannak, mint a IX-es és XI-es típusú, valamint a kizárólag a növekedési porc hypertrophyás zónájában jelen levő X-es típusú koliegén (3, 7). Ezen fehér. jéket kódoló gének mutációja áll sok jól ismert osteochondrodyspasia hátterében (6).

A porc ECM legnagyobb mennyiségben jelen lévő, nem kollagén típusú makromolekulája az aggrekán, amely egy nagy molekulasúlyú, hyaluronsav (HA) kötő képességgel rendelkező proteoglikán. A molekulához nagyszámú chondroitin-szulfát (glükózaminoglikán) oldallánc kapcsolódik, és legfőbb jellemzője, hogy egy centrális HA molekulához nagy számban kapcsolódva óriás aggregátumokat hoz létre. Az aggrekán-HA kapcsolatot egy harmadik molekuláris szereplő, a porc link protein (cartilage link protein, LP) stabilizálja. A kis molekulasúlyú (46 KDa) glikoprotein legfőbb tulajdonsága, hogy HA kötő képességgel rendelkezik. Stabilizáló hatását úgy fejti ki, hogy egyszerre kötődik a HA szálhoz és a vele szomszédos aggrekán molekulához (4). LP nélkül ezen aggregátumok nagysága és stabilitása jelentősen csökken (12), megváltoztatva az ECM összetételét és tulajdonságait. Tekintve a proteoglikánok és glikoproteinek szerepét az ECM felépítésében, az ezeket érintő mutációk kis száma meglepő. A két ismert aggrekán mutációra csak az utóbbi időben derült fény (8). LP mutáció mindmáig nem ismeretes egyik osteochondrodysplasia hátterében sem.

A dolgozat célja egy olyan állatkísérletes modell bemutatatása, amely bizonyítja a LP szerepét a chondrogenezisben a fehérje hiánya vagy csökkent mennyisége által előidézett osteochondrodysplasia vizsgálatán keresztül. Ugyanakkor bizonyítja, hogy a fehérjeszintézis helyreállítása dózis dependens módon gyógyulást eredményez.

\section{ANYAG ÉS MÓDSZER}

A jelen tanulmány alapjául szolgáló, és alábbiakban ismertetett kísérleteket a chicagoi Rush Medical Center, Department of 
Orthopaedic Surgery, Section of Biochemistry and Molecular Biology laboratóriumában végeztük.

\section{A link protein gén manipulációja}

A modell létrehozásához két genetikailag manipulált egértörzsre volt szükség. Egyrészről olyan állatokra, amelyek LP-t kódoló génje célzott mutáció (gene knockout) következtében múködésképtelen, ezért fehérjét nem termel. Heterozigóta mutáció esetén $\left(L P^{+/-}\right)$az egyedek normálisan fejlődnek, homozigóta mutáció $\left(L P^{-/}\right)$azonban súlyos osteochondrodysplasiát okoz perinatális letalitással (16). A heterozigóta tenyészállatot a National Institute of Health, Craniofacial Developmental Biology and Regeneration Branch laboratoriumából kaptuk.

Másrészről szükség volt olyan állatokra, amelyek a LP-t feleslegben termelik. Ezeket az úgynevezett transzgenikus egereket a chicagoi laboratóriumban állítottuk elő. A transzgenikus egerek genomja a saját link protein génjükön kívül egy porcspecifikus vektor segítségével bejuttatva további LP géneket (gén másolatokat) is tartalmazott (2). A tenyésztés során két törzs mutatott stabil transzgén expressziót, a transzgenikus $A$ és $C$ törzs ( $L P^{T g A}$ és $\left.L P^{\operatorname{Tg} C}\right)$.

A kísérlet során olyan állatok kitenyésztése volt a cél a két törzs (knockout és transzgenikus) keresztezésével, amelyek saját LP génjüket tekintve homozigóta mutánsok, ugyanakkor hordozzák a transzgént. A tenyésztés során az utód generációk egyedeinek genotípusát meghatároztuk, és mind a knockout mutációt, mind a transzgént hordozó egyedeket kereszteztük tovább. A kívánt genotípusú, transzgént hordozó homozigóta mutánsok ( $L P^{-1-\text { TgA+ }}$ és $L P^{-1-\operatorname{TgC+})}$ a második generációban jelentek meg. Feltételeztük, hogy a transzgének által biztosított fehérjetermelés pótolja a kiesett saját fehérjetermelést, és terápiás hatással lesz az osteochondrodysplasia elváltozásaira, de legalábbis elősegíti az egyedek túlélését.

\section{A link protein génexpresszió mérése}

A porc LP gén expresszióját real-time quantitative polymerase chain reaction (RTQT-PCR) segítségével (Smart Cycler System, Cepheid, Sunnyvale, CA) mértük. Az analízishez szükséges komplementer DNS (cDNS) mintákat újszülött egerek porcmintáiból kivont RNS-t használva állítottuk elő reverz transzkripcióval. Minden genotípushoz tartozóan három különböző alomból származó, kilenc állat két független mintáját használtuk, és mintánként három mérést végeztünk. A reakciós oldathoz LP génspecifikus primereket használtunk, és a gén expressziót a dupla szálú DNShez kötődő CYBR green festék fluoreszcenciáját valós időben (rea! tínej neérve határroztuk meg.

\section{A link protein mérése}

Az LP fehérje termelés detektálása és qantitatív analízise újszülött egerek skeletális szöveteiből készült extraktumokon, Western blot segítségével történt. Genotípusonként három vagy négy alomból származó, 9 állat fehérjemintáin végeztünk méréseket, mintánként három alkalommal. A mélyfagyasztott és porított porc mintákból a fehérje extrakció 4 mólos guanidinium klorid oldatban történt, majd a minták azok dialízise, liofilizálása és normalizálása után kerültek felhasználásra Western blot analízishez. A fehérjéket 10\%-os SDS-polyacrylamide gélen szeparáltuk, majd nitrocellulóz filterre való átvitelt követően nyúlban termeltetett LP ellenes poliklonális antitestekkel kezeltük. A másodjára hozzáadott, peroxidázzal jelölt, kecskében termeltetett nyúl-ellenes antitest a végül hozzáadott luminol szubsztráttal kemilumineszcens reakciót váltott ki. A felszabaduló fényjelenséget, amely arányos a minta LP tartalmával, röntgenfilmen rögzítettük. Előhívás után az eredményeket PDI gél scanner és szoftver segítségével értékeltük (Protein Database Inc., Huntington Station, NY).

\section{Morfológiai vizsgálatok}

$\mathrm{Az}$ osteochondralis szövetek hisztológiai vizsgálathoz kéthetes egerekből készült metszeteket használtunk. A mintákat $10 \%$-os formalinban fixáltuk, majd 12 napig $4{ }^{\circ} \mathrm{C}$-on $10 \%$-os EDTA oldatban való dekalcinálás után paraffinba ágyaztuk. A metszetek festése safranin $O$ és fast green kombinációjával történt. A készítményeket fénymikroszkóppal vizsgáltuk. A csontrendszer minőségi és mérhető változásait az állatokról készült röntgenfelvételeken tanulmányoztuk. 


\section{Statisztikai analízis}

Leíró statisztikát alkalmaztunk a csoportátlagok, standard deviációk megállapítására. Több csoport összehasonlításánál MANOVA analízist végeztünk, két kijelölt csoport öszszevetésénél Student $T$ tesztet alkalmaztunk Bonferroni korrekcióval. A szignifikanciát a $p<0,01$ szinten állapítottuk meg. A statisztikai számításokat az SPSS 10.0 statisztikai programmal végeztük (SPSS Inc., Chicago, IL, USA)

\section{EREDMÉNYEK}

\section{A genetikailag manipulált egerek túlélése}

A kiindulási feltételezésnek megfelelően azok az egyedek, amelyeknek saját LP termelésük a homozigóta mutáció miatt nem volt, de valamelyik transzgént hordozták ( $L P^{-/-T g A+}$ vagy $L P^{-/-T g C+}$ ) túléltek. Különbség volt azonban a túlélési arányokban annak megfelelően, hogy a túlélést biztosító transzgén az $A$, vagy a $C$ transzgenikus törzsből származott. A túlélési arányok a harmadik generációban stabilizálódtak úgy hogy az $A$ transzgént hordozó homozigóta knockout egerek (túlélő A csoport) aránya 12,9\%, a C transzgént hordozó homozigóta knockout egerek (túlélő C csoport) aránya pedig 21,1\% volt az összes élve születésre számítva. Összehasonlításul, a szelektív tenyésztés során a Mendeli szabályok szerint, valamint a homozigóta mutánsok szükségszerű perinatális pusztulásával is számolva a harmadik generációban várható túlélési arány 29,3\%-ban jósolható.

\section{A genetikailag manipulált egerek génexpressziója és protein termelése}

Heterozigóta knockout egerekben $\left(L P^{+-}\right)$ az LP génexpresszió kevesebb, mint fele volt mérhető, míg a fehérjetermelés $54 \pm 7 \%$ volt a vad típusú $\left(L P^{+/+}\right)$kontrollhoz képest (1. A-C ábra, 2. oszlop), ugyanakkor ezen egerek skeletális fejlődése, és születési aránya fiziológiás maradt. A homozigóta LP deficiens egerekben $\left(L P^{-1}\right)$ sem LP génexpresszió, sem fehérjetermelés nem volt kimutatható (1. A-C ábra, 3. oszlop). A real time PCR mérések nem igazoltak magasabb LP génexpressziót a transzgenikus $A$ törzsben (LP ${ }^{\mathrm{TgA}}$ ) (1. A ábra, 4. oszlop). Ugyanakkor a termelt LP fehérje mennyisége mintegy $50 \%-k a l \quad(48 \pm 24 \%)$ magasabb volt, mint a vad típusú kontrollban (1. C ábra, 4. oszlop). A transzgenikus $C$ törzsben $\left(L P^{T g C}\right)$ az LP génexpresszió legalább háromszoros volt a kontrollhoz képest (1. A ábra, 5. oszlop). Ugyanitt, a megnövekedett génexpresszióval társultan a porc LP fehérje tartalma $153 \pm 21 \%$ kal volt magasabb (1. C ábra, 5. oszlop). Mindkét túlélő csoportban alacsonyabb volt a mért LP génexpresszió a vad típusú kontrollhoz viszonyítva úgy, hogy nem várt módon a túlélő A csoport $\left(L P^{-/ \operatorname{TgAt})}\right.$ génexpressziója magasabb volt, mint a túlélő $C$ csoport $\left(L P^{-1-T g C+}\right)$ génexpressziója (1. A ábra, 6-7. oszlop). Ezzel ellentétben az LP fehérjetermelés a túlélő $C$ csoportban volt magasabb, a kontrollhoz képest annak valamivel több, mint fele $(56 \pm 6 \%)$ (1. C ábra, 7. oszlop). A túlélő A csoportban 

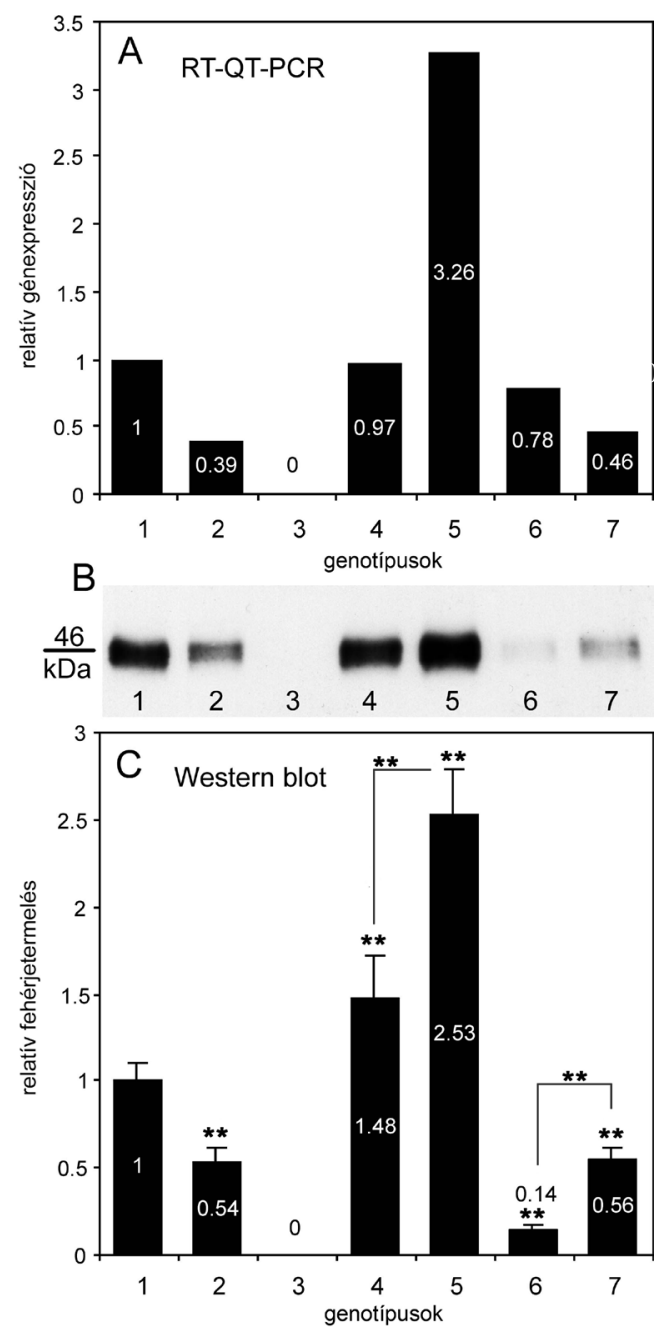

1. ábra

LP génexpresszió és fehérjetermelés quantitativ analízise. A génexpresszió mért különbségeit az A, a fehérjetermelés mért különbségeit a C ábra foglalja össze. Mindkét esetben az adatok a kontroll vad típushoz viszonyított relativ expressziót mutatják. A B ábra egy reprezentativ Western blot analizis eredményét szemlélteti. A szignifikáns különbségeket kettős csillag jelöli $\left(^{* *}=p<0,01\right)$.

A különböző genotípusokat jelölő számok:

1. kontroll vad típus $\left(L P^{+++}\right)$;

2. heterozigóta $L P$ knockout $\left(L P^{+/}\right)$;

3. homozigóta $L P$ knockout $\left(L P^{\prime}\right)$;

4. LP transzgenikus A ( $\left.L P^{T g A}\right)$;

5. LP transzgenikus C ( $\left.L P^{T g C}\right)$;

6. túlélö A csoport ( $\left(P^{-/ T g A+}\right)$;

7. túlélö C csoport (LP $\left.P^{-/ T g C+}\right)$; 
ennél kevesebb, csupán $14 \pm 3 \%$ volt mérhető (1. C ábra, 6. oszlop). A fehérjetermelés változásai minden csoportban szignifikánsak voltak $(p<0,01)$ a vad típusú kontrollhoz képest. Szignifikáns volt $(p<0,01)$ a különbség a két transzgenikus törzs és a két túlélő csoport között is (1. Cábra, 4-5. és 6-7. oszlop).

\section{A túlélö csoportok fenotípusa}

A két különböző túlélő csoportban ( $A$ és C) a transzgének (TgA és $\operatorname{TgC}$ ) által biztosított fehérje produkció eltérő szintjének megfelelően szignifikáns különbségek voltak megfigyelhetők. Azon túlmenően, hogy az alacsonyabb LP szintézist mutató $A$ csoport túlélési aránya elmaradt az erősebb $C$ csoport túlélése mögött, ezeket az állatokat szignifikánsan súlyosabb osteochondrodysplasiás elváltozások jellemezték. A túlélő $A$ csoport egyedei születéskor jóval kisebbek voltak társaiknál. Mind a törzs, mind a végtagok rövidebbek voltak, és jelentős különbségek voltak a fej nagyságában és alakjában. Az állatok orra megrövidült, a fej anteroposterior átmérője kisebb volt, az agykoponya kupolaszerű megjelenést mutatott.
A törpe növés az egyedek fejlődése során egyre kifejezettebbé vált. A hosszú csöves csontok epiphysis magjai késve jelentek meg, de a csontok meta-, és diaphysisén nem voltak morfológiai eltérések (2. B-C ábra), eltekintve az átlagosan $15 \%$-os rövidüléstől. A gerinc csigolyatestei ellapultak (2. A ábra), és jelentős sagittalis síkú görbületek alakultak ki, amelyek az életkor előrehaladtával fokozódtak. A felső thoracalis szalsaszon? hyperiordosis, àz alsć thoracalis szakaszon hyperkyphosis alakult ki. A túlélő C csoportban ezzel szemben csak nagyon enyhe skeletális elváltozások voltak megfigyelhetők (2. A-C ábra).

A növekedési porc felépítésében is jelentős eltérések voltak, elsősorban a túlélő A csoportban (2. D ábra). A növekedési porc kiszélesedett és jóval sejtszegényebb volt a kontrollnál, de a C csoport osteochondrodysplasiásaihoz viszonyítva is. A porcsejtek számának csökkenése megfigyelhető volt a proliferációs, a prehypertrophiás, és a hypertrophiás zónában egyaránt. A sejtek oszlopokba rendeződése a hypertrophiás zónában megmaradt, de a másik két zónában
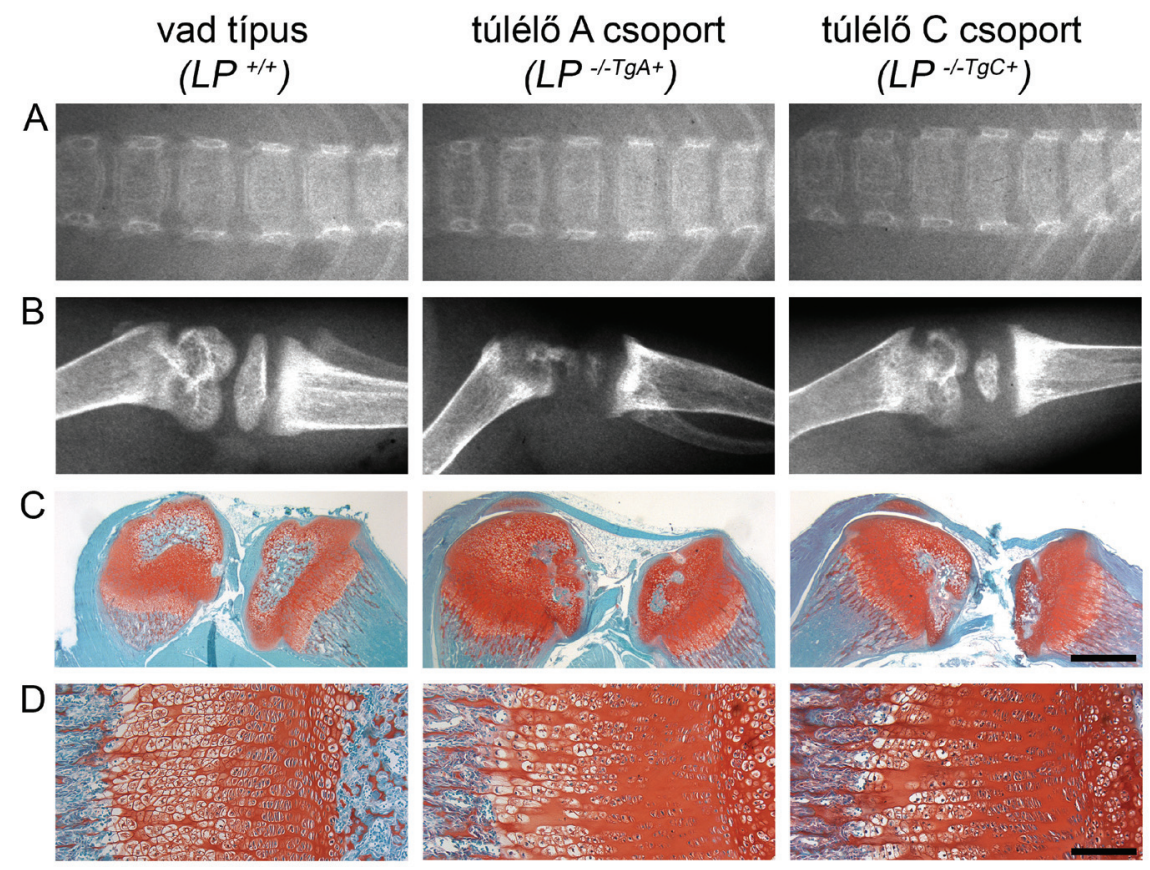

2. ábra Kéthetes egerek gerinc (A) és térd (B) röntgenfelvételei, valamint térdizületek (C) és proximalis tibia növekedési porcból készült metszetek (D) safranin O/fast green festéssel. Vonalak: C. $1 \mathrm{~mm}$, D. 200um. 
többé-kevésbé fellazult, amely a növekedési porc struktúrájának felbomlását eredményezte. A szükségszerűen megnövekedett mennyiségű ECM proteoglikánokhoz kötődő safranin $O$ festődése megmaradt mindkét túlélő csoportban. A kalcifikációs zónában kialakuló csontgerendák is elsősorban a túlélő $A$ csoportban voltak vékonyabbak.

\section{MEGBESZÉLÉS}

A humán osteochondrodysplasiák azon csoportját, amelyek hátterében a porc extracelluláris mátrixának strukturális fehérjéit kódoló gének mutációja áll, meglehetősen jól ismerjük. Ezek döntő többségét a porcspecifikus kollagének génmutációi okozzák (17). A porcban legnagyobb mennyiségben jelen lévő II-es típusú kollagént kódoló gén mutációi okozzák a spondyloepiphysealis displasia (SED) csoport kórképeit. Ide tartoznak a spektrum súlyosabb végét képviselő II-es típusú achondroplasia és hypochondrogenesis, a közepes súlyosságú SED congenita valamint a Stickler és Kniest dysplasiák. A spektrum enyhébb végén a SED tarda áll (6). A IX-es típusú kollagén defektusai multiplex epiphysealis dysplasiák (MED) két vagy több variánsát is okozzák (6). A XI-es típusú kollagén mutációja okozza például az oto-spondylo-megaepiphysealis dysplasiát, míg a X-es típusú kollagén mutációja Schmidféle metaphysealis dysplasiát eredményez (6, $8,13)$. A porc ECM glikoproteinjeit érintő ismert mutációk egyike a cartilage oligomeric matrix proteint (COMP), a másik a matrilin-3 fehérjét kódoló géneket érinti. A COMP mutáció felelős a pseudoachondroplasia és a Fairbanks típusú MED kialakulásáért, a matrilin-3 gén mutációja is egy MED variánst okoz $(8,13,17)$. Sokáig az egyetlen ismert proteoglikán mutáció a perlekánt érintette (dyssegmentális dysplasia, Schwarz-Jampel szindróma) (13), és csak az utóbbi időben derült fény a porc legfőbb proteoglikánjának, az aggrekánnak a mutációira. Két kórkép tartozik ide: egy atoszomális domináns öröklődésű, enyhe arányos alacsonynövést és korai arthrosist okozó Kimberly-féle SED, és egy súlyos törpeséggel és facialis dysmorphismussal (arckoponya hypoplasia) járó recesszíven öröklődő, úgynevezett aggrekán típusú spondyloepimetaphysealis dysplasia (8). Ismerve az aggrekán, mint strukturális építőelem jelentőségét a porc ECM óriás aggregátumainak felépítésében és a porc mechanikai tulajdonságainak kialakításában, valamint ismerve hogy ezen funkcióhoz szükség van egy másik strukturális glikoproteinre a HA szálhoz való kötődés stabilizálásához, joggal feltételezhetjük, hogy ezen stabilizáló molekula, az LP defektusa is okozhat porc strukturális eitéré. seket és humán osteochondrodysplasiát. Megjegyzendő, hogy a molekula szerepét humán osteochondrodysplasiák hátterében korábban, az akkori tudásnak megfelelően, kizárták (11).

A humán kórképekkel párhuzamba állíthatók állatokon (jelen esetben egereken) kialakuló osteochondrodysplasiák, amelyek vagy természetesen előforduló spontán mutációkon, vagy mesterségesen előidézett mutációkon alapulnak. Egereken ismert a XI-es típusú kollagén mutációja által okozott autoszomális recesszív öröklődésű osteochondrodysplasia (cho egerek). Az érintett egyedek végtagjai aránytalanul megrövidültek, szájpadhasadék és pulmonalis hypoplasia jellemzi őket. Születéskor a trachea kollapszusa halált okoz (10). Egy másik ismert autoszomális recesszíven öröklődő mutáció az egér aggrekán gént érinti, és szintén letális osteochondrodysplasiát okoz (cmd egerek). Az érintett egyedek aránytalan törpék rövidült végtagokkal, szájpadhasadékkal, rövidült orral és a születéskor légzési elégtelenség miatti halállal (14). A heterozigótákon hosszú távon gerincdeformitások alakulnak ki enyhe törpeség mellett (15). A Il-es típusú kollagén célzott mutációja a fentiekhez hasonló osteochondrodysplasiás fenotípust és perinatális letalitást okoz (9). Az LP mesterségesen előidézett célzott mutációja a homozigóta egyedeken súlyos letális osteochondrodysplasiát okoz, de a heterozigóták normálisan fejlődnek (egy ilyen heterozigóta szerepelt a jelen tanulmány kísérleteinek egyik kiindulási pontjaként). Az érintett állatok törzse és végtagjai megrövidültek, a fej jellegzetesen kupolaszerú megjelenést mutat megrövidült orral. A perinatális letalitásért itt is a légzési elégtelenség felelős, amit a respiratorikus rendszer porcos elemeinek fejletlensége okoz (16). Látható tehát, hogy minden egyes strukturális molekula teljes 
hiánya súlyos letális osteochondrodysplasiát okoz, ami nem ad lehetőséget a csontrendszer fejlődésének további tanulmányozására újszülött kor után. A mutációra heterozigóták fenotípusa ugyanakkor fiziológiás.

A jelen tanulmányban ismertetett állatmodellen az LP szintézis különböző menynyiségben történő helyreállítása képes volt megváltoztatni a súlyos kimenetelü osteochondrodysplasiát. A transzgének által diktált LP fehérjetermelés biztosította a homozigóta knockout egerek túlélését, és azok felnőtt kort értek meg. Ezen túlmenően, a termelt LP mennyiségétől függően enyhültek az osteochondrodystrophiás elváltozások. A túlélő $A$ csoportban, ahol a fehérjetermelés a normális szint $14 \%$-a volt, az egyedek ugyan túléltek, de markáns osteochondrodysplasiás elváltozásokat mutattak. A törpenövés a végtagok és a törzs jelentős rövidülésével, platyspondyliával és gerincdeformitásokkal járt, az arckoponya hypoplasiajával együtt. Ez a fenotípus a legtöbb hasonlóságot a humán SED csoportba tartozó kórképekkel mutat, amelyeknek jellegzetességei a rövidült törzs és végtagok okozta törpenövés, valamint maxillofacialis hypoplasia, szájpadhasadék, szem és belső fül eltérések (1). A legjobb analógiát a közepesen súlyos humán SED congenita nyújtja, ahol a törzs és végtagok jelentősen rövidültek, az ossificatio megkésett (egérben: lásd 2. B ábra), platyspondylia alakul ki (egérben: lásd 2. A ábra), dorsolumbalis kyphosis és kyphoscoliosis (egérben: thoracalis hyperlordosis és hyperkyphosis) van jelen. A túlélő C csoportban, ahol a normális fehérjetermelés $56 \%$-a volt mérhetö, rendkívül enyhe skeletális elváltozások maradtak vissza, amely az LP hiánya által kiváltott osteochondrodysplasia sikeres génterápiáját jelenti.
Modellünket összevetve az irodalomban fellelhető, és korábban említett, spontán vagy mesterségesen előidézett porc ECM protein mutáción alapuló osteochondrodysplasia modellekkel, az alapvető különbség a kiváltó fehérje hiány „szabályozott” volta. Látható, hogy minden egyes strukturális molekula (XI-es és II-es típusú kollegén, aggrekán, LP) teljes hiánya súlyos letális osteochondrodysplasiát okoz $(9,10,15,16)$, ami nem ać lehetóséget a csontrendszer fejlődésének további tanulmányozására újszülött kor után. A mutációra heterozigóták fenotípusa ugyanakkor fiziológiás. A szerzők tudomása szerint az itt bemutatott modell egyedülálló abban a tekintetben, hogy lehetőséget ad az osteochondrodysplasia jellegzetességeinek nyomon követésére születés után, valamint támpontot ad arra vonatkozóan, hogy egy adott strukturális molekula milyen mértékű hiánya vezet letalitáshoz, vagy csontrendszeri eltérések megjelenéséhez.

Eredményeink bizonyítják egyetlen strukturális protein jelentőségét a porc ECM szerkezetének fenntartásában, a chondrogenezisben és a skeletális fejlődésben. Annak ellenére, hogy az LP szerepére humán osteochondrodysplasiák kialakulásában mindmáig nincs bizonyíték, nem kizárható, hogy létezik olyan osteochondrodysplasia, amelynek okozója az LP gén mutációja. Modellünk alapján spondyloepiphysealis megjelenés jósolható, és valószínúleg recesszív öröklésmenet. Az is lehetséges azonban, hogy az LP szerepe túlmutat egy egyszerű strukturális ECM molekulán, és kiesése már az intrauterin élet során súlyos következményekkel járva magzati halálozáshoz vezet, ami az osteochondrodysplasiás fenotípus klinikai megfigyelését lehetetlenné teszi. 


\section{IRODALOM}

1. Bálint G.., Szebenyi B.: Hereditary disorders mimicking and/or causing premature osteoarthritis. Bailliere's Clinical Rheumatology. 2000. 14: 219-250.

2. Czipri M., Otto J. M., Cs-Szabó G.., Kamath R. V., Vermes C., Firneisz G.., Kolman K. J., Watanabe H., Li Y., Roughley P. J., Yamada Y., Olsen B. R., Glant T. T.: Genetic rescue of chondrodysplasia and the perinatal lethal effect of cartilage link protein deficiency. J. Biol. Chem. 2003. 278: 39214-39233.

3. Gannon J., Walker G., Fischer M., Carpenter R., Thompson Jr. R. C., Oegema Jr. T. R.: Localization of type X collagen in canine growth plate and adult canine articular cartilage. J. Orthop. Res. 1991. 1: 485-494.

4. Hardingham T. E.: The role of link-protein in the structure of cartilage proteoglycan aggregates. Biochem. J. 1979. 177: 237-247.

5. Horton W. A.: In vitro chondrogenesis in human chondrodysplasias. Am. J. Med. Genet. 1993. 45: 1;9-182.

6. Horton W. A.: Progress in human chondrodysplasias: molecular genetics. Ann. N. Y. Acad. Sci. 1996. 785: $150-159$.

7. Kannu P., Bateman J. F., Belluoccio D., Fosang A. J., Savarirayan R.: Employing molecular genetics of chondrodysplasias to inform the study of osteoarthritis. Arthritis Rheum. 2009. 60: 325-334.

8. Krakow D., Rimoin D.L.: The skeletal dysplasias. Genetics in Medicine. 2010. 12: 327-341.

9. Li S. W., Prockop D. J., Helminen H., Fassler R., Lapvetelainen T., Kiraly K., Peltarri A., Arokoski J., Lui H., Arita M. et al.: Transgenic mice with targeted inactivation of the Col2a1 gene for collagen II develop a skeleton with membranous and periosteal bone but no endochondral bone. Genes Dev. 1995. 9: 2821-2830.

10. Li Y., Lacerda D. A., Warman M. L., Beier D. R., Yoshioka H., Ninomiya Y., Oxford J. T., Morris N. P., Andrikopoulos K, Ramirez F. et al.: A fibrillar collagen gene, Col11a1, is essential for skeletal morphogenesis. Cell. 1995. 80: 423-430.

11. Loughlin J., Irven C., Sykes B.: Exclusion of the cartilage link protein and the cartilage matrix protein genes as the mutant loci in several heritable chondrodysplasias. Hum. Genet. 1994. 94: 698-700.

12. Morgelin M., Paulsson M., Hardingham T. E., Heinegård D., Engel J.: Cartilage proteoglycans. Assembly with hyaluronate and link protein as studied by electron microscopy. Biochem. J. 1988. 253: 175-185.

13. Superti-Furga A., Bonafe L., Rimoin D. L.: Molecular-pathogenetic classification of genetic disorders of the skeleton. Am. J. Med. Genet. 2001. 106: 282-293.

14. Watanabe H., Kimata K., Line S., Strong D., Gao L. Y., Kozak C. A., Yamada Y.: Mouse cartilage matrix deficiency (cmd) caused by $a 7$ bp deletion in the aggrecan gene. Nature Genet. 1994. 7: 154-157.

15. Watanabe H., Nakata K., Kimata K., Nakanishi I., Yamada Y.: Dwarfism and age-associated spinal degeneration of heterozygote cmd mice defective in aggrecan. Proc. Natl. Acad. Sci. 1997. 94: 6943-6947.

16. Watanabe H., Yamada Y.: Mice lacking link protein develop dwarfism and craniofacial abnormalities. Nature Genet. 1999. 21: 225-229.

17. Warman M. L., Cormier-Daire V., Hall C., Krakow D., Lachman R., LeMerrer M., Mortier G., Mundlos S., Nishimura G., Rimoin D. L., Robertson S., Savarirayan R., Sillence D., Spranger J., Unger S., Zabel B., Superti-Furga A.: Nosology and classification of genetic skeletal disorders 2010 revision. Am. J. Med. Genet. Part A. 2011. 155: 943-968.

\section{Dr. Czipri Mátyás}

Royal Devon and Exeter Hospital, Princess Elizabeth Orthopaedic Centre

Barrack Road, Exeter, UK, EX2 5DW

E-mail: matyas.czipri@nhs.net 